\title{
Effect of Combustion Chamber Shapes on the Performance of Duel Fuel Engine Operated on Rice Bran Oil Methyl Ester and Producer Gas
}

Nataraj Kashipura ${ }^{1}$, Banapurmath NR $^{2 *}$, Manavendra $\mathbf{G}^{3}$, Nagaraj AM ${ }^{3}$, Yaliwal VS ${ }^{4}$, Vaibhav Kulkarni ${ }^{2}$ and Satish Gokak ${ }^{2}$

${ }^{1}$ J.S.S. College of Engineering and Technology, Bangalore, Karnataka, India

${ }^{2}$ B.V.B. College of Engineering and Technology, Hubli, Karnataka, India

${ }^{3}$ B.I.E.T College of Engineering and Technology, Davangere, Karnataka, India

${ }^{4}$ S.D.M. College of Engineering and Technology, Dharwad 580002, Karnataka, India

\begin{abstract}
Shape of combustion chamber plays a major role in controlling of combustion process and emission mechanisms occurring inside the combustion chamber. To implement ideal combustion chamber facilitates are essential to meet emission norms. In this context an experimental investigation were carried out on a single cylinder four stroke direct injection diesel engine operated in dual fuel mode using Rice bran oil methyl ester (ROME) and Coconut shell wood derived producer gas. ROME is used as a pilot injected fuel which ignites the producer gas and air mixture when subjected to higher compression ratio. In the present work, different combustion chamber shapes were designed and developed by keeping the same compression ratio of existing diesel engine. The engine makes use of the hemispherical combustion chamber (HCC) shape. In order to study the effect of other combustion chamber shapes on the performance of dual fuel engine, Cylindrical (CCC), Trapezoidal ( $\operatorname{TCC}$ ), and Toroidal combustion chamber (TCC) shapes were used. Various engine parameters such as power, torque, fuel consumption, and exhaust temperature, combustion parameters such as heat release rate, ignition delay, combustion duration, and exhaust emissions such as smoke opacity, hydrocarbon, $\mathrm{CO}$, and NOx, were measured. Results revealed that the TCC shape resulted in overall improved performance with reduced emission levels compared to other shapes tested. Total hydrocarbon emission (THC) and carbon monoxide (CO) were also decreased significantly compared to other combustion chambers tested. Results reveal that more information may be positive in terms of improvement in exhaust emissions. Nevertheless, some positive conclusions have been reached for TCC as a result of this work.
\end{abstract}

Keywords: Biodiesel; Rice bran oil methyl ester; Biomass; Producer gas; Emissions; Combustion chamber shapes

\section{Introduction}

Diesel engines are widely used for transport and power generation applications because of their high thermal efficiency, and their easy adoption for power generation applications has been increasing recently. However, there is demand for better performance, lower noise and vibration and greater levels of lower emissions and also due to increasing energy demand, decrease in fossil fuel reserve in the earth crust and harmful exhaust gases have focused major attention on renewable and alternative fuels. To overcome and in meeting these demands, the dual fuel engine, enabling the use of renewable fuels such as biodiesels and producer gas attracts much attention. To meet the challenge, it is essential in implementing new technologies and methods that improve the efficiency of dual fuel engine used for transport and power generation. Renewable energy sources can supply the energy for longer periods of time than that of fossil fuels and have many advantages [1]. Liquid biodiesels are more suitable for diesel engine applications as their properties are closer to diesel [2]. The main challenge facing by producer gas fueled dual fuel engine include the limited range of operability, quality of producer gas and sensitivity to air/fuel mixture preparation as well as in-cylinder combustion related conditions. Ho wever, there are some significant obstacles facing the potential practical application of producer gas combustion in a dual fuel engine. In light of the importance of air/fuel mixture preparation and combustion related conditions to producer gas fueled dual fuel engine and the influence of Combustion Chamber shapes on air-fuel mixture preparation mainly drives the output of an engine.

Biodiesels derived from vegetable oils gives slightly lower performance with reduced emissions [3-9]. Effect of various engine parameters such as compression ratio (CR), injection timing (IT) and engine loading (L) on the performance and exhaust emissions of a single cylinder diesel engine using biodiesel and blends with diesel fuel were reported [10-14]. Biomass gasifier projects for decentralized power supply and financial evaluation has been reported in the literature [15,16]. Many investigators have extensively studied gasifierengine systems for both rural and urban power applications [6,7,912,15-18]. The dual fuel engine with producer gas induction results in higher thermal efficiency with reduced emission levels at higher compression ratio and advanced injection timing. Higher Exhaust Gas Temperature [EGT] than diesel fuel with fixed injection timing and compression ratio were also reported $[3,13,14,19]$. The major problem associated with producer-gas operated engines is their power-derating. The producer gas operated dual fuel engine always operate with lower efficiency and increased HC and CO emission levels with decreased NOx and smoke emission levels. Diesel savings up to $70-90 \%$ has been reported for dual fuelling [3,6,7,9-22]. Effect of carburetor type and biomass feedstock properties on the performance and emission characteristics of dual fuel engine has been reported in the literature $[6,7,13,17,19]$. Some of the investigators have reported decreased brake thermal efficiency, peak pressure, heat release rate and increased specific energy consumption, ignition delay and combustion duration for dual fuel operation [12-14,17,20-22]. The effects of engine speeds, loads, pilot injection angle, pilot fuel quantity and compression ratio on combustion noise, knocking torque, thermal efficiency and maximum pressure were investigated for the natural gas fuelled dual fuel engine [23]. In the case of producer-gas dual fuelling a suitable carburetor

${ }^{*}$ Corresponding author: Banapurmath NR, B.V.B. College of Engineering and Technology, Hubli, Karnataka, India, Tel: 91-9880726748; E-mail: nr_banapurmath@rediffmail.com

Received April 18, 2015; Accepted May 06, 2015; Published May 13, 2015

Citation: Kashipura N, Banapurmath NR, Manavendra G, Nagaraj AM, Yaliwal VS et al. (2015) Effect of Combustion Chamber Shapes on the Performance of Duel Fuel Engine Operated on Rice Bran Oil Methyl Ester and Producer Gas. J Pet Environ Biotechnol 6: 225. doi:10.4172/2157-7463.1000225

Copyright: (c) 2015 Kashipura N, et al. This is an open-access article distributed under the terms of the Creative Commons Attribution License, which permits unrestricted use, distribution, and reproduction in any medium, provided the original author and source are credited. 
Citation: Kashipura N, Banapurmath NR, Manavendra G, Nagaraj AM, Yaliwal VS, et al. (2015) Effect of Combustion Chamber Shapes on the Performance of Duel Fuel Engine Operated on Rice Bran Oil Methyl Ester and Producer Gas. J Pet Environ Biotechnol 6: 225. doi:10.4172/2157-7463.1000225

Page 2 of 8

was used to provide a mixture of appropriate pre-defined air-to-fuel $(\mathrm{A} / \mathrm{F})$ ratio to the engine over the entire range of engine operation $[3,13,17]$. The combustion chamber of an engine plays a major role during the combustion of wide variety of fuels. In this context, many researchers were performed both experimental and simulation studies on the use of various combustion chambers [17,24-27]. Improvement in air entrainment with increasing swirl and injection pressure was reported $[28,29]$. Optimum combustion chamber geometry of engine must be considered to have a better engine operation, performance and emission levels. Suitable combustion geometry of bowl shape helps to increase squish area and proper mixing of gaseous fuel with air $[25,30]$. Designing the combustion chamber with narrow and deep and with a shallow reentrance and a low protuberance on the cylinder axis while the spray should be oriented towards the bowl entrance reduces the NOx emission levels to the maximum extent [3]. The behavior of fuel once it is injected in the combustion chamber and its interaction with air is important. It is well known that nozzle geometry and cavitations strongly affect to evaporation and atomization processes of fuel. Suitable changes in the in-cylinder flow field resulted in differing combustion. In this context, experimental investigations were carried out on single cylinder four stroke direct injection diesel engine operated on dual fuel mode using Rice bran oil methyl ester (ROME) and producer gas derived from coco nut shell. Effective combustion chamber results a swirl and it leads to increasing efficiency, reducing of noise and other emission pollutants, and improving combustion instability.

In this present work an effort has been made to evaluate feasibility of alternative renewable fuels in the form of Rice bran oil methyl ester (ROME) and producer gas as a complete replacement for fossil fuels. In view of this, experiments have been conducted on a single cylinder four-stroke CI engine operated on dual fuel mode with four types of combustion chambers (cylindrical (CCC), trapezoidal (TrCC), and toroidal Combustion chamber (TCC) shapes) and at an advanced injection timing of $270 \mathrm{bTDC}$, injection pressure of 205 bar for diesel injection in Diesel-Producer gas combination and 230 bar for biodiesel in ROME-Producer gas operation. An injector having four holes each having an orifice diameter of $0.2 \mathrm{~mm}$ were used for the reported work. These optimum parameters in terms of advanced injection timing (270 bTDC), increased injection pressure (230 bar), injector (4 holes, 0.2 $\mathrm{mm}$ orifice) and compression ratio were reported in earlier studies by the same authors (Banapurmath, 2008, 2009, 2011).

\section{Characterization of ROME and Producer Gas}

In the present study, Diesel and ROME as injected fuels and the producer gas derived from coconut shell as an inducted fuel were used. Acaia nilotica Linn is a tree, belonging to the Leguminosae family and sub-family of Mimosavea. The properties of ROME and gasifier feed stock were determined experimentally and are summarized in Table 1.

\section{Experimental Setup}

Experiments were conducted on a Kirloskar TV1 type, four stroke, single cylinder, water-cooled diesel engine test rig. Figure 1 shows the schematic experimental set up. Eddy current dynamometer was used for loading the engine. The fuel flow rate was measured on the volumetric basis using a burette and stopwatch. The engine was operated at a rated constant speed of $1500 \mathrm{rev} / \mathrm{min}$. The down draft gasifier was suitably connected to the engine with filter and cooling and cleaning system (Figure 2). Producer gas was generated using a downdraft gasifier and is taken inside the combustion chamber by the suction of the engine. The gas flow was measured using a digital gas flow meter. Cooling of the engine was accomplished by circulating water through the jackets of the engine block and cylinder head. Figure 3 shows the gas entry carburetor for producer gas induction fitted to the inlet manifold of the engine. In the present work, amount/quantity of both injected fuels of

\begin{tabular}{|c|c|c|c|c|c|}
\hline $\begin{array}{r}\text { SI } \\
\text { No }\end{array}$ & Properties & Diesel & ROME & $\begin{array}{c}\text { Coconut shell derived } \\
\text { biomass }\end{array}$ & Composition \\
\hline 1 & $\begin{array}{c}\text { Viscosity @ } \\
40^{\circ} \mathrm{C}(\mathrm{cst})\end{array}$ & $\begin{array}{c}4.59 \\
(\mathrm{Low})\end{array}$ & 5.8 & Moisture Content, \% w/w & 11.9 \\
\hline 2 & $\begin{array}{c}\text { Flash point }{ }^{\circ} \mathrm{C} \\
56\end{array}$ & 172 & Ash Content, \% w/w & 0.79 \\
\hline 3 & $\begin{array}{c}\text { Calorific Value } \\
\text { in kJ/kg }\end{array}$ & 45000 & 38,010 & Volatile Matter, \% w/w & 85.8 \\
\hline 4 & Specific gravity & 0.830 & 0.870 & Fixed Carbon \% w/w & 13.4 \\
\hline 5 & Density Kg/m ${ }^{3}$ & 830 & 870 & Sulphur, \% w/w & 0.05 \\
\hline 8 & Type of oil & ---- & $\begin{array}{c}\text { Non } \\
\text { edible }\end{array}$ & Nitrogen, as N\% w/w & 0.25 \\
\hline 9 & Cetane number & 42 & 54 & Gross Calorific value, Cal/g & 4171 \\
\hline 10 & ------ & ----- & ----- & Density, $\mathrm{kg} / \mathrm{m}^{3}$ & 288 \\
\hline
\end{tabular}

Table 1: Properties of fuels tested.

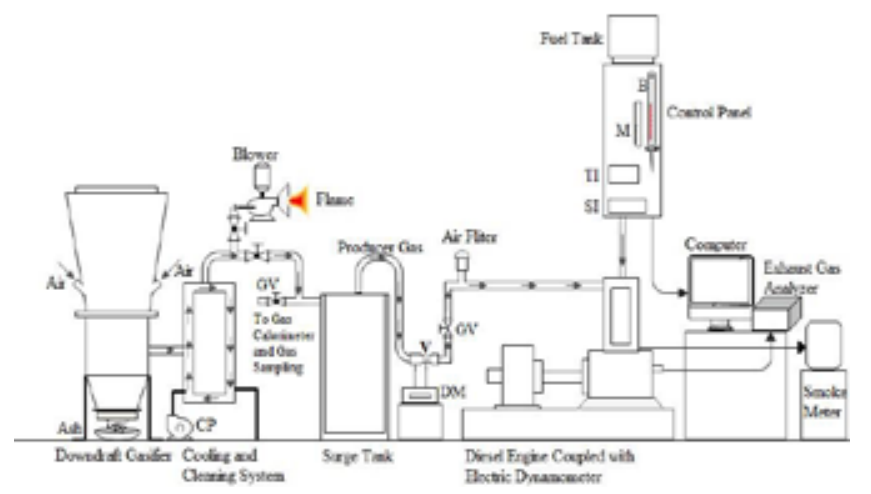

Figure 1: Schematic diagram of the test rig.

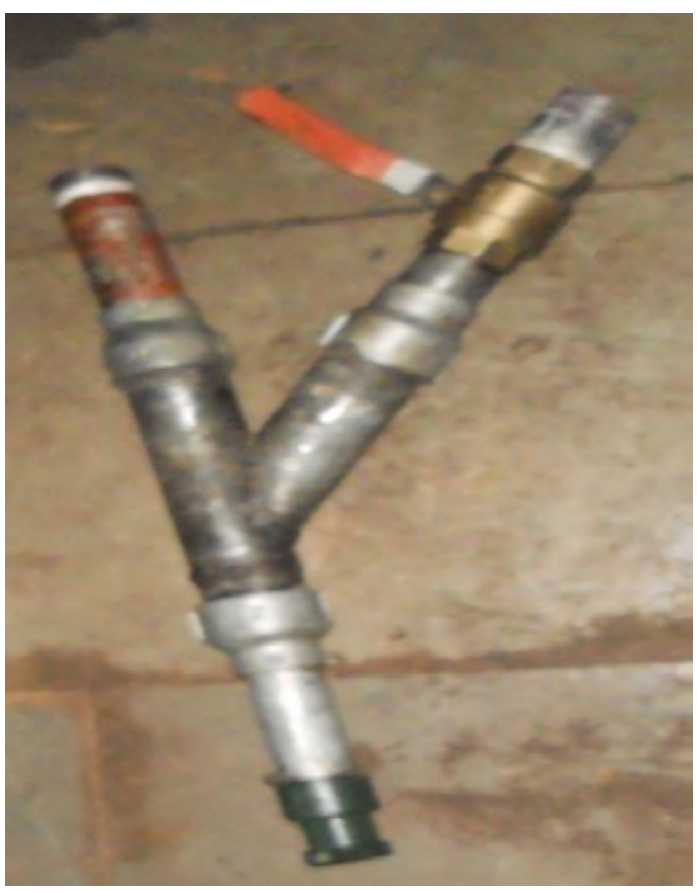

Figure 2: Carburetor for producer gas supply to the engine. 
Citation: Kashipura N, Banapurmath NR, Manavendra G, Nagaraj AM, Yaliwal VS, et al. (2015) Effect of Combustion Chamber Shapes on the Performance of Duel Fuel Engine Operated on Rice Bran Oil Methyl Ester and Producer Gas. J Pet Environ Biotechnol 6: 225. doi:10.4172/2157-7463.1000225

Page 3 of 8

Diesel and ROME have been measured on volumetric basis. At fixed brake power more amount of ROME is injected as its calorific value is comparatively lower and also its kinematic viscosity is higher (nearly twice diesel). This is done by adjusting the governor speed so that constant speed is maintained in both the versions of the injected fuels. At $80 \%$ load the SFC for diesel operation is $260 \mathrm{~g} / \mathrm{kWh}$ while for ROME it is $280 \mathrm{~g} / \mathrm{kWh}$. The emission characteristics were measured by using HARTRIDGE smoke meter and five gas analyzer during the steady state operation. During the complete experimentation, the gas flow rate and engine speed were maintained constant. For the present work, the injection timing was kept constant at $270 \mathrm{bTDC}$, injection pressure and compression ratio at 17.5 for Diesel-Producer gas and ROMEProducer gas operation were 205 bars, 230 bars and compression ratio at 17.5 respectively. Conventional mechanical injection system was used for the liquid fuel injection. Experiments were conducted by using ROME-producer gas with four different combustion chamber shapes (cylindrical (CCC), trapezoidal (TrCC), and toroidal Combustion chamber (TCC) shapes). Figures $4 \mathrm{a}-4 \mathrm{~d}$ shows the different combustion chamber shapes. Finally the results obtained with ROME-Producer gas operation was compared with Diesel-producer gas operation. The specification of the compression ignition (CI) engine and down draft gasifier is given in Tables 2 and 3.

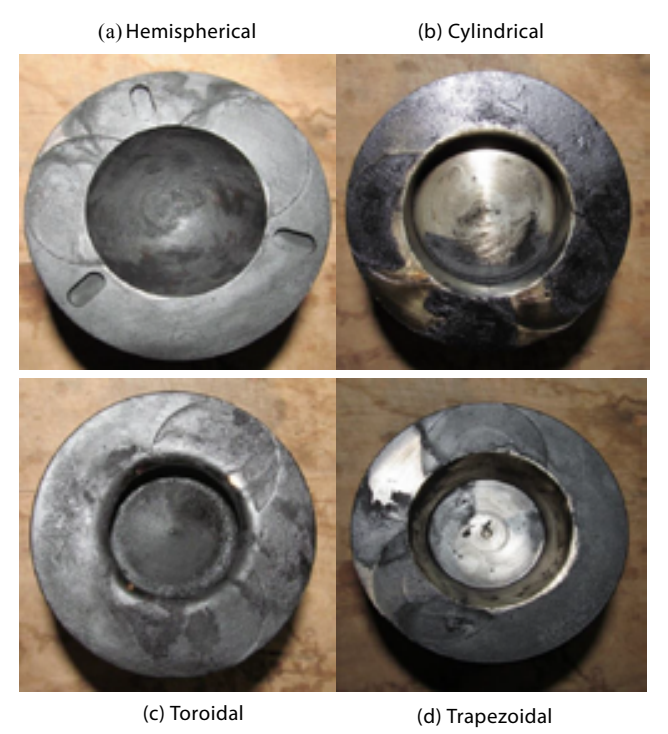

Figure 3: Combustion chamber shapes

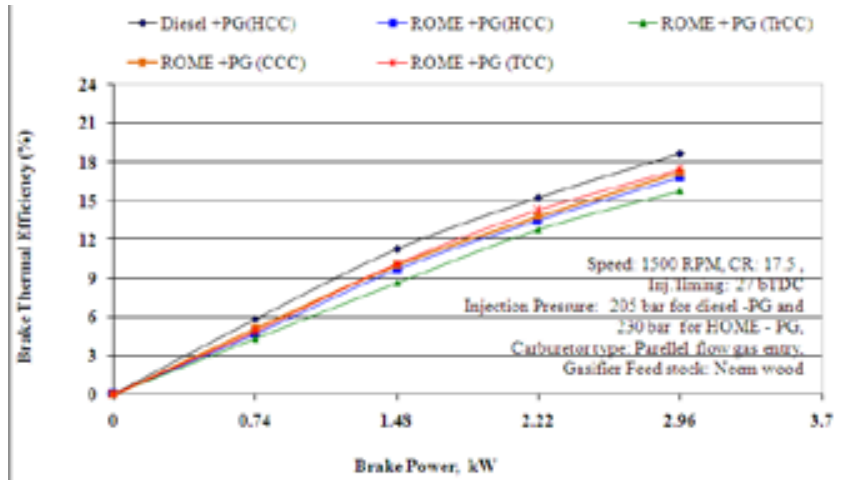

Figure 4: Variation BTE with BP.

\section{Results and Discussions}

In the present work, diesel engine was operated on dual fuel mode using diesel, ROME along with producer gas with different configurations of combustion chambers namely cylindrical (CCC), trapezoidal (TrCC), and toroidal combustion chamber (TCC) shapes. The results and discussions on the performance combustion and emission characteristics of producer gas fueled diesel engine operating on ROME-Producer gas are presented in the following sections.

\section{Performance and emission parameters}

Figure 4 shows the variation of brake thermal efficiency (BTE) with brake power. It is observed that BTE for producer gas-diesel dual fuel mode of operation was higher than ROME-Producer gas operation over the entire load range. This is mainly due to lower calorific value of ROME and producer gas. Lower flame velocity of producer gas during the ROME-Producer gas operation along with injected fuel has a major effect on the engine performance. The study with different combustion chamber shapes show that the ROME-Producer gas operation with TCC results in better performance compared to dual fuel operation with other combustion chambers. It may be due to the fact that, the TCC prevents the flame from spreading over to the squish region resulting in better mixture formation of ROME and along with producer gas-air combinations, as a result of better air motion and lowers exhaust soot by increasing swirl and tumble. Based on the results, It is observed that the TCC has an ability to direct the flow field inside the sub volume at all engine loads and therefore substantial differences in the mixing process may not be present. The BTE values for ROME-PG operation with HCC, CCC, TrCC and TCC were found to be 16.8, 15.75, 17.01 and $17.45 \%$ compared to $18.65 \%$ for diesel-producer gas operation with respectively with HCC.

The variations of exhaust gas temperature (EGT) for dieselproducer gas and ROME-producer gas operation with respect to various combustion chambers are presented in Figure 5. With HCC, TrCC and CCC, it is observed that, combustion temperature is lower; hence the unburnt hydrocarbon burns during the diffusion combustion phase rather than premixed combustion phase. Hence, this combustion chamber shapes results in to the increased exhaust gas

\begin{tabular}{|c|c|c|}
\hline SI No & Parameters & Specification \\
\hline 1 & Type of engine & $\begin{array}{c}\text { Kirlosker make Single cylinder four stroke } \\
\text { direct injection diesel engine }\end{array}$ \\
\hline 2 & Nozzle opening pressure & 200 to 205 bar \\
\hline 3 & Rated power & $5.2 \mathrm{KW}(7 \mathrm{HP}) @ 1500$ RPM \\
\hline 4 & Cylinder diameter (Bore) & $87.5 \mathrm{~mm}$ \\
\hline 5 & Stroke length & $110 \mathrm{~mm}$ \\
\hline 6 & Compression ratio & $17.5: 1$ \\
\hline
\end{tabular}

Table 2: Specifications of the engine.

\begin{tabular}{|c|c|}
\hline \multicolumn{2}{|c|}{ Down draft gasifer } \\
\hline Type & \begin{tabular}{c} 
Downdraft gasifier \\
\hline Supplier
\end{tabular} \\
\hline Rated capacity & $\begin{array}{c}\text { Ankur Scientific Energy Technologies } \\
\text { Pvt. Ltd., Baroda. }\end{array}$ \\
\hline Rated Gas flow & $62735 \mathrm{~kJ} / \mathrm{h}$ \\
\hline Average gas calorific value & $15 \mathrm{Nm} / \mathrm{h}$ \\
\hline Rated woody biomass consumption & $5-5.6 \mathrm{MJ} / \mathrm{m}^{3}$ \\
\hline Hopper storage capacity & $5-6 \mathrm{~kg} / \mathrm{h}$ \\
\hline Typical conversion efficiency & $40 \mathrm{~kg}$ \\
\hline
\end{tabular}

Table 3: Specifications of the down draft gasifier. 
Citation: Kashipura N, Banapurmath NR, Manavendra G, Nagaraj AM, Yaliwal VS, et al. (2015) Effect of Combustion Chamber Shapes on the Performance of Duel Fuel Engine Operated on Rice Bran Oil Methyl Ester and Producer Gas. J Pet Environ Biotechnol 6: 225. doi:10.4172/2157-7463.1000225

Page 4 of 8

temperature. However, lower EGT was observed with TCC. It could be attributed to correcting mixing of air and fuel due to higher range turbulence created in the combustion chamber and higher combustion temperature, this favorable condition results in higher power output and efficiency. Reduced burning of fuel combinations in the diffusion combustion phase with TCC is also responsible for this trend. The results are in line with those reported in a literature using biodiesels (V.V. Pratiba Bharathi 2011, Jaichander, 2012, Raheman and Ghadge 2008; Muralidharan and vasudevan 2011). However, higher EGT was observed for other combustion chamber configurations. It could be due to burning of the fuel combination during diffusion combustion phase. The EGT values for ROME-PG operation with HCC, CCC, TrCC and TCC were found to be $476,510,445$ and $426^{\circ} \mathrm{C}$ compared to $410^{\circ} \mathrm{C}$ for diesel-producer gas operation with respectively with HCC.

Figure 6 shows variation of volumetric efficiency for ROMEproducer operation with different combustion chamber shapes. The volumetric efficiency indicates breathing ability of an engine. A drop in volumetric efficiency with power output for all the fuel combinations was observed. It may be due to higher gas temperature and increase in temperature of inlet valve and combustion chamber walls. This feature decreases the density of induced air, and hence, the drop in volumetric efficiency. However, the part of the air replaced by producer gas further adds for this trend. Diesel-producer gas operation was resulted in better volumetric efficiency compared to ROME-producer gas combinations. It could be due to improper utilization of air as more

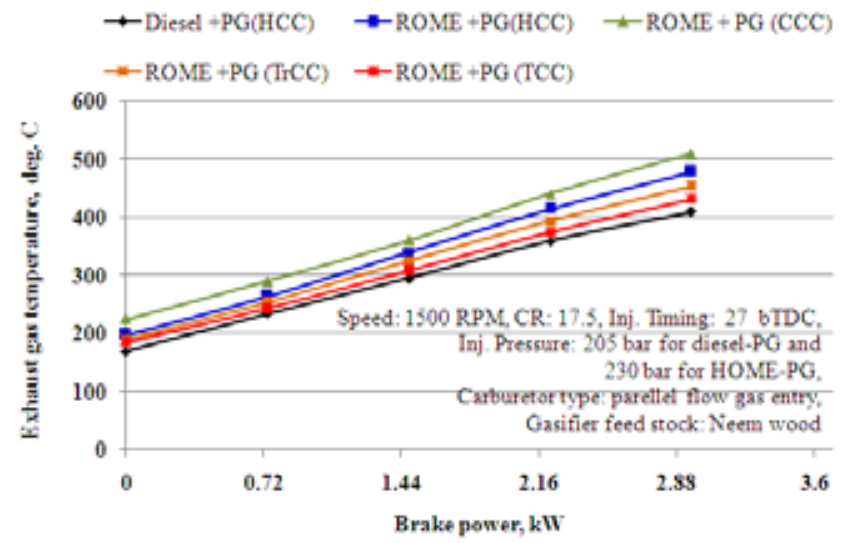

Figure 5: Variation of exhaust gas temperature with BP.

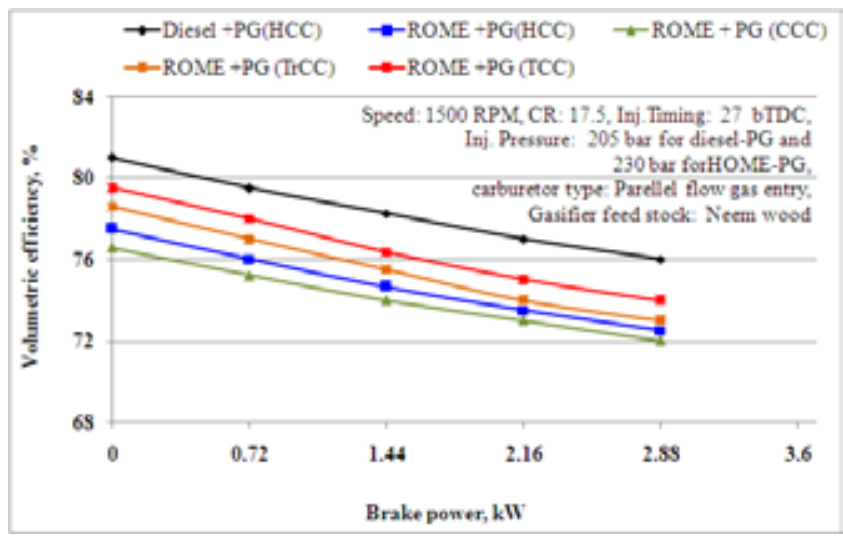

Figure 6: Variation of volumetric efficiency with BP.
ROME is injected for the same power generation with producer gas in dual fuel combinations. However, slightly higher volumetric efficiency was observed with TCC compared to other combustion chamber shapes. It may be due to the fact that, in case of TCC, at the end of compression stroke complete air-fuel mixture combination trapped in the cylinder and gets ignited immediately. At which almost piston reaches the TDC and squishes the fuel combination from the sides in to the sub volume. Then the squish of the air and fuel mixture generates a very fast and turbulent velocity which results in to better combustion and utilizes complete air available in the combustion chamber. The volumetric efficiency for ROME-PG operation with HCC, CCC, TrCC and TCC were found to be $72.91,72.12,72.86$ and $74.00 \%$ compared to $76.10 \%$ for diesel-producer gas operation with respectively with HCC.

Figure 3 shows that the variation of smoke opacity with brake power. It is observed that the smoke opacity for Producer gas-diesel dual fuel operations was lower than ROME-Producer gas over the entire load range. This may be due to improper fuel-air mixing due to higher viscosity of ROME and higher free fatty acid content of ROME. However, the study with different combustion chambers shows that, TCC gives lower smoke emission levels compared to other combustion chambers. It may be due to the fact that, the prevailing air-fuel mixing and higher turbulence in the combustion chamber result better combustion and oxidation of the soot particles which further reduce the smoke emission levels. The smoke emission levels for ROME-PG operation with HCC, CCC, TrCC and TCC were found to be 51, 58, 42, and $35 \mathrm{HSU}$ compared to $32 \mathrm{HSU}$ for diesel-producer gas operation with respectively with HCC (Figure 7).

Figures 4 and 5 shows the variation of hydrocarbon (HC) and carbon monoxide (CO) emission levels for diesel-producer gas operation with all loads. Both $\mathrm{HC}$ and $\mathrm{CO}$ emission levels are higher for ROME-producer operation compared to diesel-producer gas operation. It could be due to incomplete combustion of the ROME-producer gas combination. The incomplete combustion resulted in case of dual fuel mode of operation is due insufficient oxygen available for combustion, lower calorific value of ROME and producer gas, lower adiabatic flame temperature and higher viscosity of ROME and lower mean effective pressures are also responsible for higher $\mathrm{HC}$ and $\mathrm{CO}$ emission levels. However, combustion with ROME-Producer gas operation with TCC resulted in lower $\mathrm{HC}$ and $\mathrm{CO}$ emission levels compared to other combustion chamber shapes. It could be due to higher turbulence and comparatively higher temperature in the combustion chamber, minimum heat losses and better oxidation of $\mathrm{HC}$ and $\mathrm{CO}$ improved and which reduces the both emission levels i.e. better combustion of ROME with better mixture formation of ROME and air along with

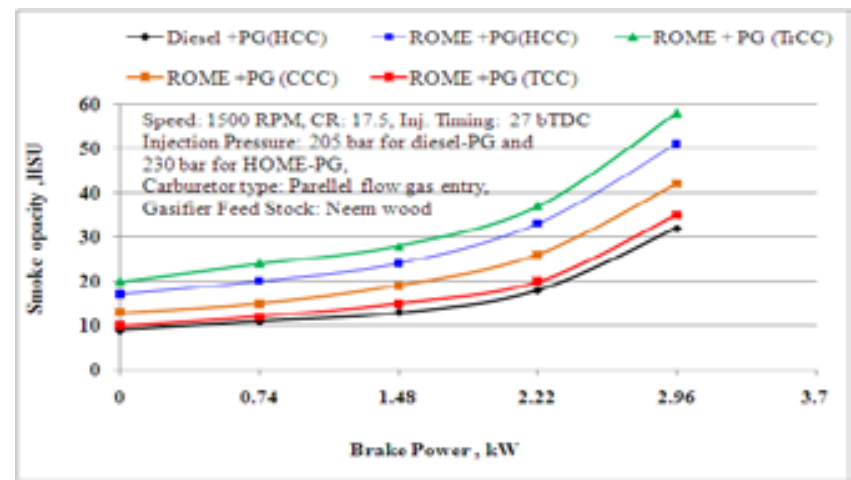

Figure 7: Variation of Smoke opacity with BP 
Citation: Kashipura N, Banapurmath NR, Manavendra G, Nagaraj AM, Yaliwal VS, et al. (2015) Effect of Combustion Chamber Shapes on the Performance of Duel Fuel Engine Operated on Rice Bran Oil Methyl Ester and Producer Gas. J Pet Environ Biotechnol 6: 225. doi:10.4172/2157-7463.1000225

Page 5 of 8

producer gas due to improved swirl motion of air. Also, higher oxygen present in the ROME leads to better combustion with TCC. However, other combustion chambers may not contribute to the proper mixing fuel combinations; It may be due to confinement in the inferior part of the bowl by the vortex generated by the HCC, CCC and TrCC. The HC levels for ROME-PG operation with HCC, CCC, TrCC and TCC were found to be 44, 55, 48 and $46 \mathrm{ppm}$, compared to $38 \mathrm{ppm}$ for dieselproducer gas operation respectively with HCC. Similarly, CO levels for ROME-PG operation with HCC, CCC, TrCC and TCC were found to be $0.46,0.42,0.39$ and $0.37 \%$ compared to $0.31 \%$ for diesel-producer gas operation respectively with HCC (Figures 8 and 9).

The NOx emission levels were found to be higher for dieselproducer gas dual fuel operation compared to ROME-Producer gas operation over the entire load range (Figure 6). This is because of higher heat release rate during premixed combustion phase occurs with diesel-producer combination compared to ROME-Producer gas combination. Slightly higher NOx is resulted from ROME-producer operation with TCC compared to the operation with other combustion chambers tested. This could be due to slightly better combustion occurs due to more homogeneous mixing and larger part of combustion occurs just before top dead center. Presence of oxygen in a ROME is also responsible for this trend. Therefore it is resulted in higher peak cycle temperature. The NOx emission levels for ROME-PG operation with HCC, CCC, TrCC and TCC were found to be 90, 65, 88 and $95 \mathrm{ppm}$, compared to $109 \mathrm{ppm}$ for diesel-producer gas operation respectively with HCC (Figure 10).

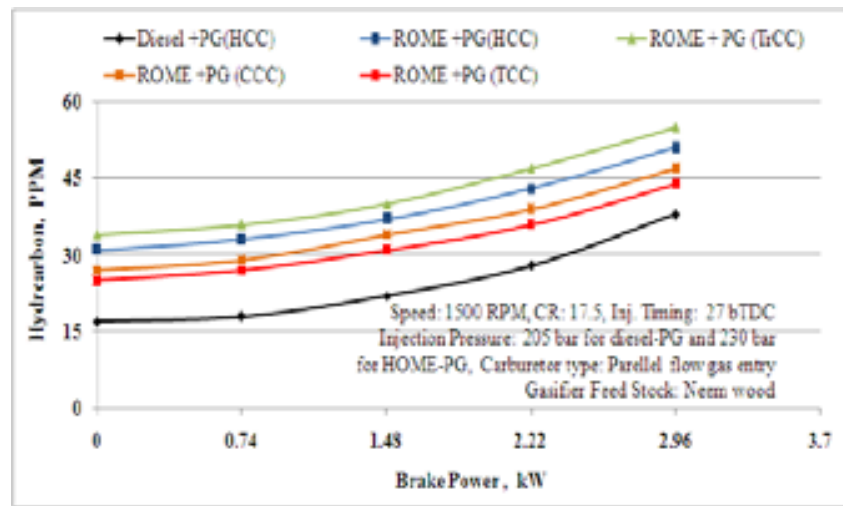

Figure 8: Variation of $\mathrm{HC}$ with $\mathrm{BP}$.

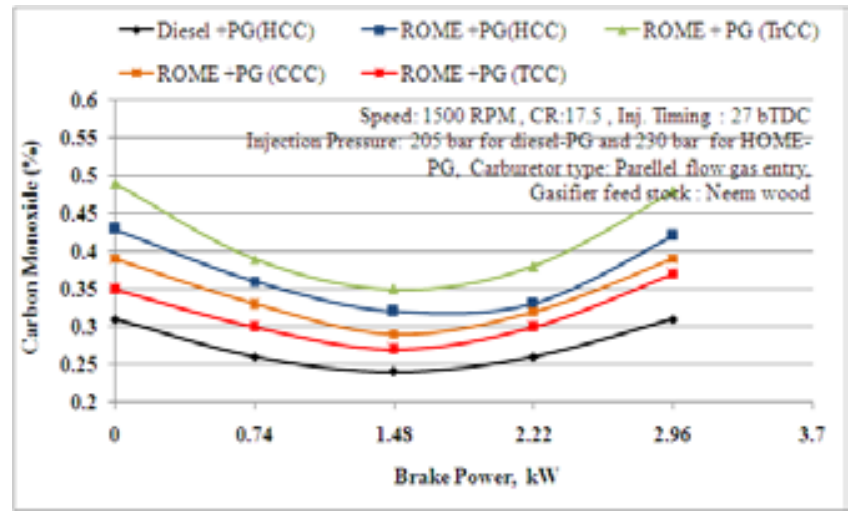

Figure 9: Variation of $\mathrm{CO}$ with BP.
Figure 11 shows the fuel substitution for dual fuel operation at different compression ratios. The maximum fuel substitution is given prime importance in dual fuel mode of operation and it depends on injected fuel's physico-chemical properties such as cetane number, viscosity and calorific value and basic engine design. Fuel substitution values were higher for TCC. TCC improves brake thermal efficiency and lowers specific fuel consumption. This means lesser fuel is consumed with TCC and hence allowing more producer gas burning for the same power output. The percentage of fuel substituted with TCC is $49 \%$ with ROME -producer gas and with HCC, CCC and TrCC's and with ROME-producer gas were reported as 41,43 and $49 \%$ respectively at $80 \%$ load. However, Maximum fuel saving is $56 \%$ for diesel-producer gas operation with HCC.

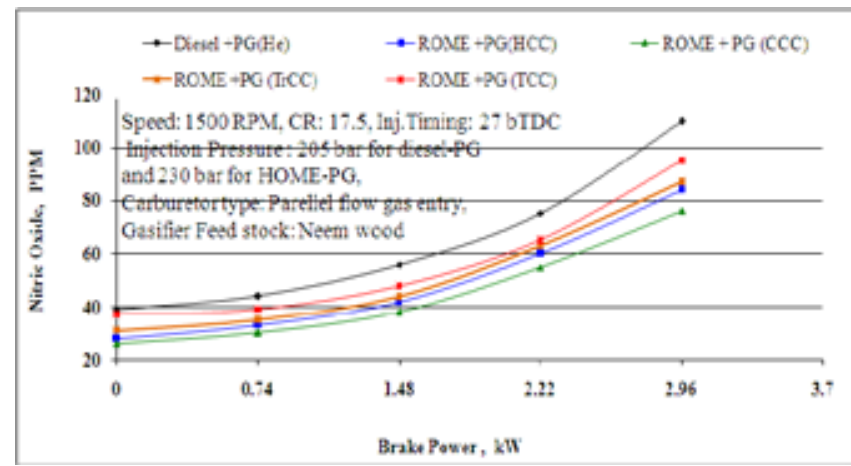

Figure 10: Variation of $\mathrm{NOx}$ with $\mathrm{BP}$.

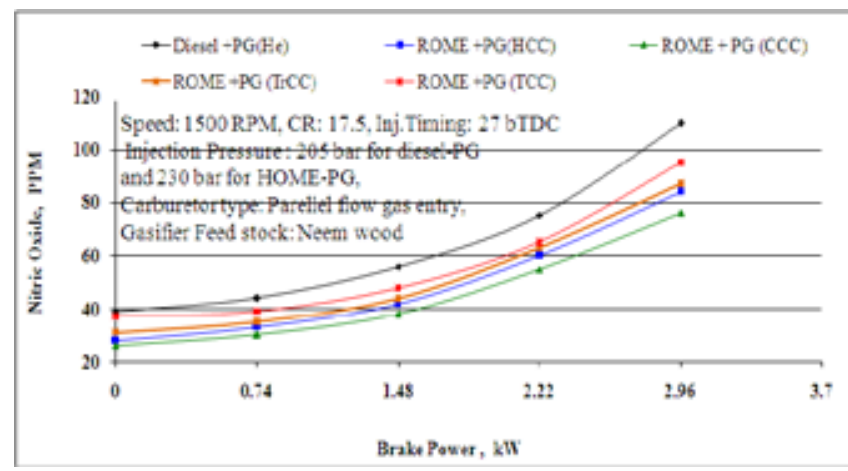

Figure 10: Variation of NOx with BP.

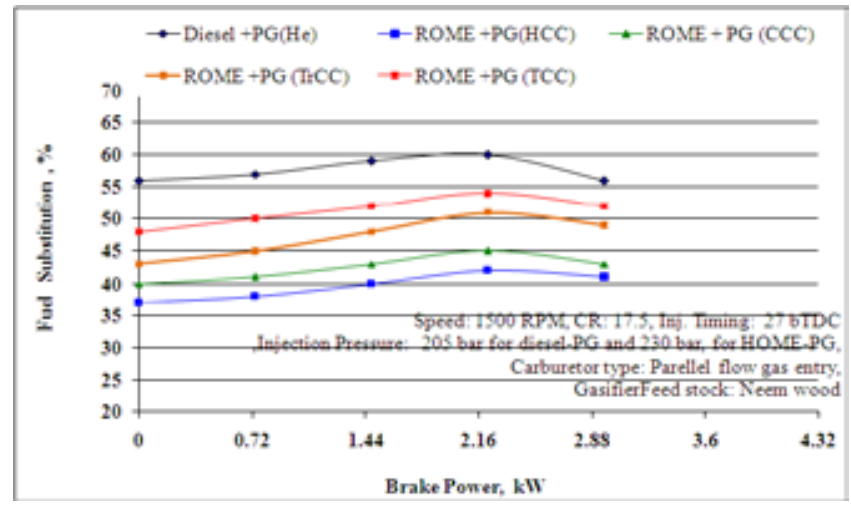

Figure 11: Variation of NOx with BP. 
Citation: Kashipura N, Banapurmath NR, Manavendra G, Nagaraj AM, Yaliwal VS, et al. (2015) Effect of Combustion Chamber Shapes on the Performance of Duel Fuel Engine Operated on Rice Bran Oil Methyl Ester and Producer Gas. J Pet Environ Biotechnol 6: 225. doi:10.4172/2157-7463.1000225

Page 6 of 8

\section{Combustion Parameters}

\section{Peak pressure}

The variations of peak pressure for diesel-producer gas and ROME-producer gas operation with respect to various combustion chambers are presented in Figure 12. Higher peak pressure was observed with TCC compared to HCC, CCC and TrCC. This may be due to better burning of the fuel combination at rapid combustion phase and decreased diffusion combustion phase occurring at higher CR. However, with same combustion chamber (HCC), peak pressure with ROME-producer gas combination under dual fuel mode of operation was found to be lower compared to diesel-producer gas operation. This may be due to combined effect of lower calorific value of ROME and producer gas, lower flame velocity, higher viscosity and density of ROME leading to poor combustion at rapid combustion phase. The peak pressure obtained for ROME-producer gas combination at 15, 16 and $17.5 \mathrm{CR}$ were $65,69.89$ and 71.8 bar compared to 77 bar for dieselproducer gas operation respectively.

\section{Ignition delay}

The variation of ignition delay with brake power for different combustion chamber shapes were shown in Figure 4. The ignition delay is calculated based on the static injection timing. Dual fuel operation with ROME -producer gas operation and with different combustion chamber shapes show variations in an ignition delay. It is observed that ignition delay is decreased with an increase in brake power for almost all combustion chamber shapes. With an increase in brake power, the amount of fuel being burnt inside the cylinder gets increased and subsequently the temperature of in-cylinder gases gets increased. This leads to reduced ignition delay with all combustion chamber shapes. However, the ignition delay for diesel-producer gas combination was lower with HCC compared to ROME-producer gas operation with combustion chamber shapes. With same combustion chamber (HCC), ROME-producer gas operation show longer ignition delay compared to diesel-producer gas operation. This may be due to the variations in the air-producer gas mixture, lower calorific value of both ROME and producer gas, lower flame temperature of producer gas, higher viscosity of ROME. Hence it requires more time for burning. However, lower ignition delays were observed for ROME-producer gas operation with TCC compared to the operation with HCC, CCC and TrCC. It could be attributed to better air-fuel mixing and increased combustion temperature. The ignition delay obtained for ROME-producer gas combination with HCC, CCC, TrCC and TCC were found to be 19.8, $18,56,17.12$ and $16.25^{\circ} \mathrm{CA}$ compared to at $14.9^{\circ} \mathrm{CA}$ for diesel-producer gas operation with $\mathrm{HCC}$ respectively (Figure 13).

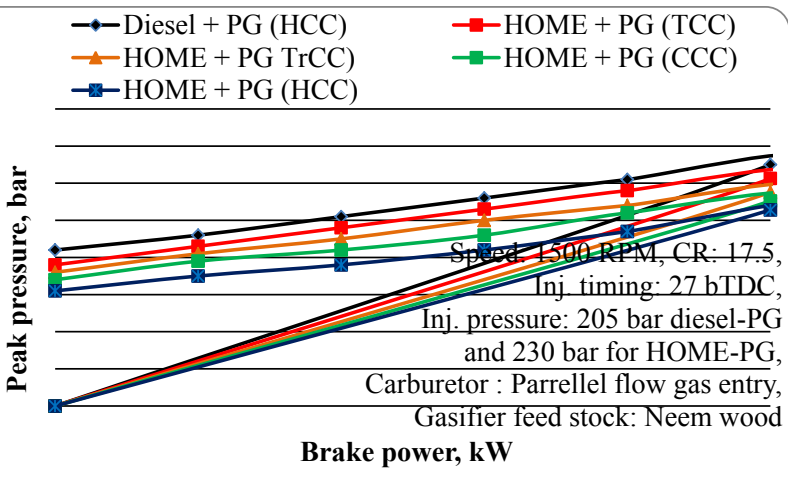

Figure 12: Variation of peak pressure with brake power.

\section{Combustion duration}

The combustion duration shown in Figure 14 was calculated based on the duration between the start of combustion and $90 \%$ cumulative heat release. The combustion duration increases with increase in the power output with all combustion chamber shapes. This is due to the amount of fuel being burnt inside the cylinder gets increased. Combustion chamber being same, higher combustion duration was observed with ROME -Producer gas combination compared to dieselproducer gas operation. It is could be due to higher viscosity of ROME leading to improper air-fuel mixing, and needs longer time for mixing and hence resulting incomplete combustion with longer diffusion combustion phase. lower adiabatic flame temperature of producer gas and high viscosity of ROME and reduced heat release rate obtained with ROME-Producer gas are also responsible for this trend. However, from the Figure 14, it is observed that the combustion duration for ROME-Producer gas operation was reduced and improved with TCC compared to other combustion chambers tested. This could be attributed to improvement in mixing of fuel combination due to better squish. Significantly higher combustion rates with ROME-Producer gas operation leads to higher exhaust temperatures and lower thermal efficiency. However, ROME-Producer gas operation with TCC shows improvement in heat release rate compared to the operation of ROMEProducer gas operation with other combustion chamber shapes. The combustion duration obtained for ROME-producer gas combination with HCC, CCC, TrCC and TCC were found to be 39.8, 39.65, 38.45 and $38.25^{\circ} \mathrm{CA}$ compared to $35.8^{\circ} \mathrm{CA}$ for diesel-producer gas operation with HCC respectively.

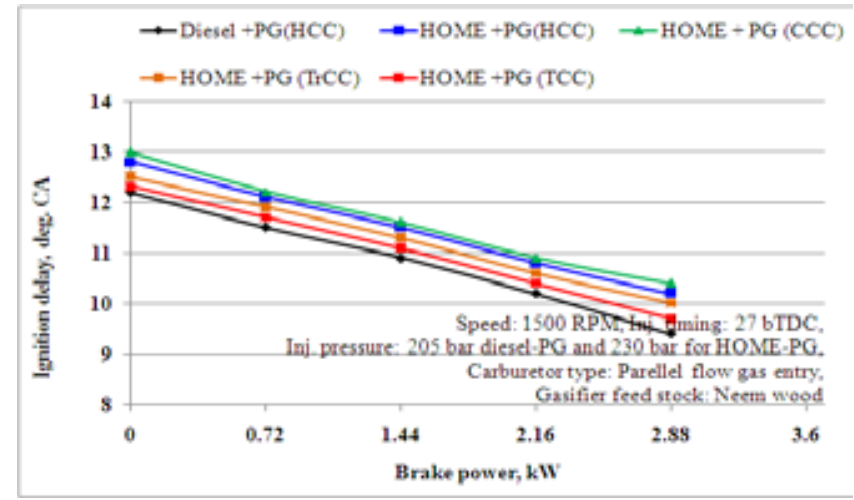

Figure 13: Variation of ignition delay with $\mathrm{BP}$.

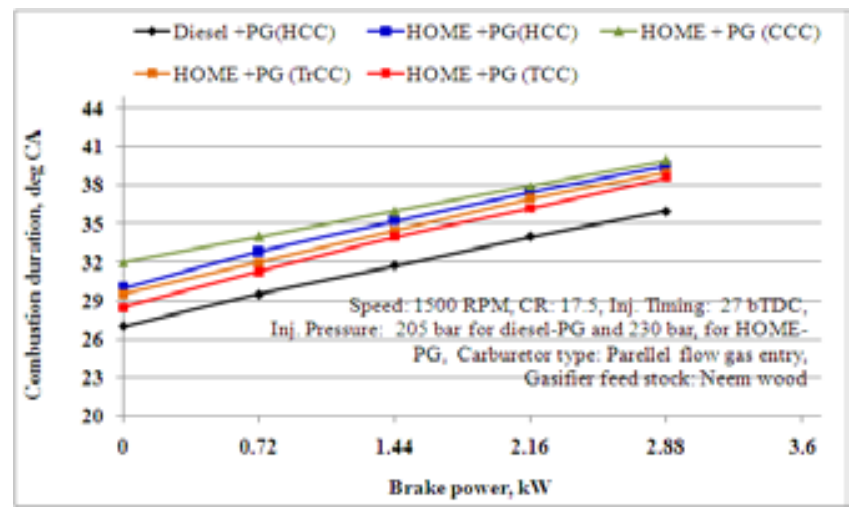

Figure 14: Variation of combustion duration with BP 
Citation: Kashipura N, Banapurmath NR, Manavendra G, Nagaraj AM, Yaliwal VS, et al. (2015) Effect of Combustion Chamber Shapes on the Performance of Duel Fuel Engine Operated on Rice Bran Oil Methyl Ester and Producer Gas. J Pet Environ Biotechnol 6: 225. doi:10.4172/2157-7463.1000225

Page 7 of 8

Cylinder pressure: Figure 15 shows effect of combustion chamber shapes on the in-cylinder pressure operated on different fuel combination. The peak pressure depends on the combustion rate and amount of fuel consumed during rapid combustion period. Mixture preparation and slow burning nature of producer gas during the ignition delay period are responsible for peak pressure and maximum rate of pressure rise.

Results showed that ROME-producer gas with TCC results in higher peak pressure as shown in Figure 15. The pressure for ROMEproducer gas operation with TCC is higher compared to ROMEproducer gas operation with other combustion chamber shapes tested. It could be due to the combined effect of longer ignition delay, lower adiabatic flame temperature and slow burning nature of the producer gas. Based on the results obtained, second peak during the diffusion burning phase was observed for ROME-producer gas combination with HCC, CCC and TrCC. This could be attributed to incomplete combustion due to improper mixing of fuel combinations, reduction of air entrainment, higher viscosity of ROME, and poor quality producer gas. The sharp increase in combustion acceleration shows increase in cylinder pressure during the piston's descent and that the combustion energy is efficiently converted into work.

Heat release rate: Figure 16 shows rate of heat release versus crank angle for different ROME -Producer gas combinations with different

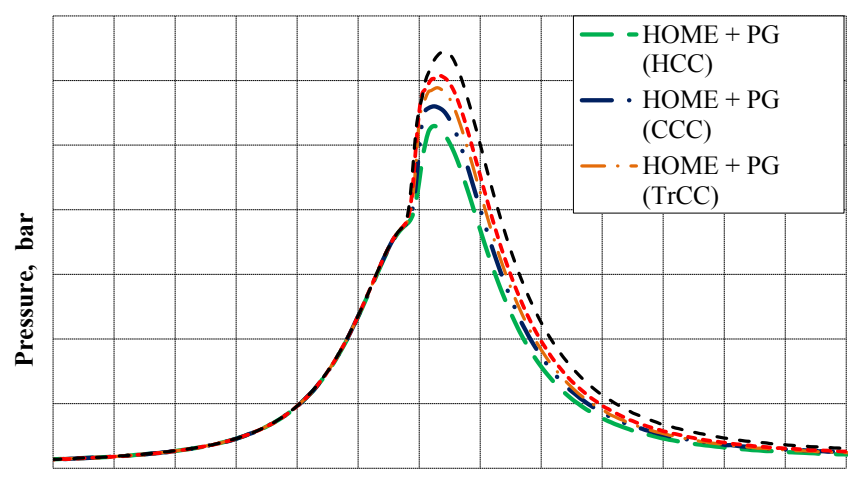

Crank angle, degree $\mathrm{CA}$

Figure 15: In-cylinder pressure versus crank angle at varying compression ratio for ROME -Producer gas combinations at $80 \%$ load.

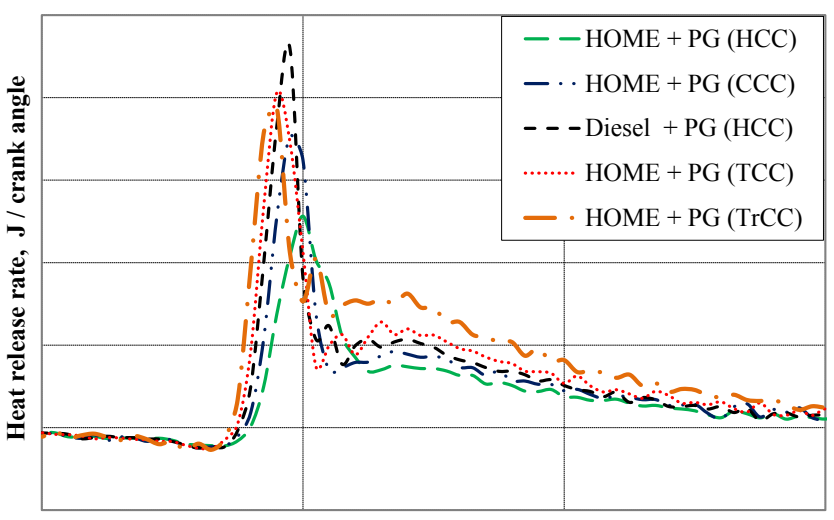

Crank angle, degree CA

Figure 16: Rate of heat release versus crank angle at varying compression ratio for ROME -Producer gas combinations at $80 \%$ load. combustion chamber shapes. ROME -Producer gas operation for HCC, CCC and TrCC results in lower heat release rate compared to the operation with TCC. This is due to the result of higher second peak obtained HCC, CCC and TrCC in the diffusion combustion phase compared to the dual fuel operation with TCC operation.

\section{Conclusions}

The following conclusions were made for the present study.

- The power de-rating in producer gas operated dual fuel engine is of the order of $30 \%$. The power output of the engine used is $3.7 \mathrm{~kW}$, and the engine is operated at less than $80 \%$ of the load.

- Improved air motion, better mixture formation or homogeneous fuel and air mixing is possible with TCC compared to other combustion chambers tested.

- Higher brake thermal efficiency with lower emission levels obtained with TCC.

- For better performance, combustion chamber optimization is not only the deciding factor. But also accurate optimization of injector position is necessary to have a larger reduction in emissions.

- Producer gas having lower flame velocity leads to lower mean effective pressure. This is necessary to achieve by developing combustion chamber specifically for producer gas. Improving turbulence in the combustion chamber leads to improved mixing of fuel combinations, also improving the breathing capacity of the engine resulting in an increased flame speed.

- Optimizing the injection geometry is essential for proposed combustion chamber. Therefore, effect of nozzle geometry and equivalence ratio on the performance should be studied to have good insight into combustion chamber design and associated combustion and emissions.

\section{References}

1. Goldemberg J, Coelhobn ST (2004) Renewable energy-traditional biomass vs modern biomass. Energy Policy 32: 711-714.

2. Sridhar G, Sridhar HV, Basavaraj MS, Sudarshan HI, Somsekhar, Dasappa S, Paul PJ (2008) Case study on distributed decentralized generation based biomass gasifier system. The Energy and Resources Institute (TERI), New Delhi, pp. 1-15.

3. Banapurmath NR, Tewari PG (2009) Combustion characteristics of a 4-stroke $\mathrm{Cl}$ engine operated on Honge oil, Neem and Rice Bran oils when directly injected and dual fuelled with producer gas induction. Renewable Energy 34 1877-1884.

4. Nwafor OMI (2000) Effect of advanced injection timing on the performance of rapeseed oil in diesel engines. Renewable Energy 21: 433-444.

5. Nwafor OMI (2003) The effect of elevated fuel inlet temperature on performance of diesel engine running on neat vegetable oil at constant speed conditions. Renewable Energy 28: 171-181.

6. Parikh PP, Bhave AG, Kapse DV, Shashikantha S (1989) Study of Therma and Emission Performance of Small Gasifier-Dual-Fuel Engine Systems. Biomass 19: 75-97.

7. Ramadas AS, Jayaraj S, Muralidharan C (2006) Power generation using coir pith and wood derived producer gas in a diesel engine. Fuel processing technology 87: 849-853.

8. Scholl KW, Sorenson SC (1993) Combustion analysis of soyabean oil methyl ester in a direct injection diesel engine. Society of Automotive Engineers, pp. 930-934.

9. Singh RN, Singh SP, Pathak BS (2007) Investigations on operation of $\mathrm{Cl}$ engine using producer gas and rice bran oil in mixed fuel mode. Renewable Energy 32: 1565-1580. 
Citation: Kashipura N, Banapurmath NR, Manavendra G, Nagaraj AM, Yaliwal VS, et al. (2015) Effect of Combustion Chamber Shapes on the Performance of Duel Fuel Engine Operated on Rice Bran Oil Methyl Ester and Producer Gas. J Pet Environ Biotechnol 6: 225. doi:10.4172/2157-7463.1000225

Page 8 of 8

10. Muralidharan K, Vasudevan D (2011) Performance, emission and combustion characteristics of a variable compression ratio engine using methyl esters of waste cooking oil and diesel blends. Applied Energy 88: 3959-3968.

11. Raheman H, Ghadge SV (2008) Performance of diesel engine with biodiese at varying compression ratio and ignition timing. Agricultural and Food Engineering Department. Fuel 87: 2659-2666.

12. Sridhar G, Sridhar HV, Dasappa S, Paul PJ, Rajan NKS, Mukunda HS (2005) Development of producer gas engines. Proc. IMechE Part D: Journal of. Automobile Engineering 219: 423-438.

13. Banapurmath NR, Yaliwal VS, Satish Kambalimath, Hunashyal AM, Tewari PG (2011) Effect of Wood Type and Carburetor on the Performance of Producer Gas-Biodiesel Operated Dual Fuel Engines. Waste and Biomass Valorization, Springer Publications, pp. 1-11.

14. Sahoo BB, Sahoo N, Saha UK (2009) Effect of engine parameters and type of gaseous fuel on the performance of dual-fuel gas diesel engines-A critical review. Renewable and Sustainable Energy Reviews 13: 1151-1184.

15. Ravindranath NH, Balachandra P (2009) Sustainable bioenergy for India: Technical, economic and policy analysis. Energy 34: 1003-1013

16. Nouni MR, Mullick SC, Kandpal TC (2007) Biomass gasifier projects for decentralized power supply in India: A financial evaluation. Energy Policy 35 $1373-1385$.

17. Banapurmath NR, Tewari PG, Hosmath RS (2008) Experimental investigations of a four-stroke single cylinder direct injection diesel engine operated on dual fuel mode with producer gas as inducted fuel and Honge oil and its methyl ester (HOME) as injected fuels. Renewable Energy 33: 2007-2018.

18. Cenk Sayin, Metin Gumus (2011) Impact of compression ratio and injection parameters on the performance and emissions of a DI diesel engine fueled with biodiesel-blended diesel fuel. Applied Thermal Engineering 31: 3182-3188.

19. Samir JD, Lalit BB, Shashikant BT (2008) Investigation on performance and emission characteristics of $\mathrm{Cl}$ engine fuelled with producer gas and esters of Hingan (Balanites) oil in dual fuel mode. International Journal of Mechanical Systems Science and Engineering 2: 148-153.
20. Roy MM, Eiji T, Nobuyuki K, Yuji H, Atsushi S (2009) Performance and emission comparison of a supercharged dual-fuel engine fueled by producer gases with varying hydrogen content. International Journal of Hydrogen Energy 34: 7811-7822.

21. Karim GA, Gao J (1993) Developing a knock predictive criterion in spark ignition engines fuelled with gaseous fuels. Journal of Thermal Science 2: 304-311.

22. Karim GA, Jones W, Raine RR (1989) An Examination of the Ignition Delay Period in Dual Fuel Engines, SAE International, Paper Number: 892140.

23. Mohamed YES (2004) Sensitivity of dual fuel engine combustion and knocking limits to gaseous fuel composition Energy. Energy Conversion and Management 45: 411-425.

24. Arbon IM (2002) Worldwide Use of Biomass in Power Generation and Combined Heat and Power Schemes. Journal of Power and Energy, Proc. Instn. Mech. Engrs. Part-D, 216: 41-57.

25. Arturo de Risi, Teresa D, Domenico L (2003) Optimization of combustion chamber of direct injection diesel engines. SAE International, Paper No. 200301-1064.

26. Jaichander S, Annamalai K (2012) Performance and exhaust emission analysis on pongamia biodiesel with different open combustion chambers in a DI diesel engine. Journal of Scientific and Industrial Research 71: 487-491.

27. Matsumoto K, Inoue T, Nakanishi K Okumura T (1977) The effects of combustion chamber design and compression ratio on emissions, fuel economy and octain number requirement. Society of Automotive Engineers.

28. Bharathi Pratiba VV, Prasanthi G (2011) Influence of in cylinder air swirls on diesel engine performance and emission. Applied Engineering and Technology 1: 113-118.

29. McCracken ME, Abraham J (2001) Swirl-Spray Interactions in a Diesel Engine. Society of Automotive Engineers.

30. Tanaji BS (2012) Experimental investigation on effect of combustion chamber geometry and port fuel injection system for CNG engine. IOSR Journal of Engineering 2: 49-54. 